\title{
Könyvszemle
}

SIPOS JÚLIA GONDOZÁSÁBAN

\section{GAZDASÁGI, POLITIKAI ÉS TÁRSADALMI KIHÍVÁSOK A 21. SZÁZADBAN}

Az ünnepi kötet címe arra enged következtetni, hogy az olvasó igen szerteágazó, a jelenkor problémáit a lehető legszélesebb értelemben feltáró müvet tart a kezében, és ebben nem is kell csalódnia. Halmai Pétert ugyanis kollégái, barátai, pályatársai olyan munkával lepték meg 65 . születésnapja alkalmából, amely áttekinti a több évtizedes tudósi-oktatói és tudományos közéleti életút legfontosabb állomásait.

Az ünnepi köszöntőt követően a négy szerkezeti egységre tagolt mü hủen követi ennek a pályafutásnak legfontosabb mozzanatait, amelynek kezdetét a Múltidéző címü bevezető fejezet adja. Az oktatói és kutatói életút kezdeti, kiemelkedő eredményei is a múlt, így az előző rendszer agrárrendszerének átfogó kritikai elemzéséhez kapcsolódnak. Ez a fejezet ennél is nagyobb vállalást tesz a sokszínü és történelmileg átfogó múltidézést felvázolva. Így elemzi az Európai Tanácsadó Bizottság szerepét Németország megosztásában, a választottbíráskodás vallás- és gazdaságtörténeti gyökereit - egészen a bibliai időkig visszanyúlva. A múltidézés során térnek ki a kollégák a 20. századi fejlődés-gazdaságtan egyik kiváló müvelőjének, Sir Peter Thomas Bauernek a munkásságára, a hadászati és védelempolitikai elemzések pedig ugyancsak e század ágazati kihívásait, így a 31. harckocsiezred 1968-as tevékenységét és a védelem-gazdaságtan korábbi és jelenlegi helyzetét veszik számba. Nem kívánjuk a teljesség akárcsak látszatát kelteni, ám érdemes minden fejezet egy-egy kitünő írását néhány mondat erejéig ismertetni. A Múltidézés keretében a kötet az európai integráció egyik alapító atyjának - Robert Schumannak - az életútjával foglalkozik, így a francia és német gyökerek szülte kettősséggel, a két világháború viszontagságai által kiváltott felismerések fontosságával, amelyek elvezettek a Schuman-nyilatkozat elhangzásáig, amely egyúttal Európa (újjászületésének) napját is jelenti az utókor számára. Hamza Gábor még nagyobb vállalást tesz, mivel számba veszi, hogy ezen európai életútra a 19. század végi és 20. század elején és közepén hódító eszmeáramlatok, a francia-német kiegyezés szükségességének felismerése miképpen hatott ki, valamint kitér Schuman Magyarországhoz füződő kapcsolataira is.

Európa és hazánk meghatározottsága a globális térben Halmai Péter munkásságának is központi eleme. Pályatársai az Atalakuló világ címü fejezetben sorra 
veszik azokat a kihívásokat, amelyek óhatatlanul kihatnak a 21. századi globális fejlődési folyamatokra. Így e fejezet tárgyalja a globalizáció kifulladásának jeleit, az ünnepelt munkásságában is kiemelkedő jelentőségủ növekedési gazdaságtan meghatározó tényezőit - számba véve annak diverzitás, innováció, nemzetközi munkaerö-áramlás általi meghatározottságát. A szerzők a gazdasági és szociális követelmények hatására a munkaszerződések megítélésekor, a humántőke, a vezetői szerepkör és a strukturális reformálhatóság kérdéseit is elemzik. A kitekintés nemcsak az egyén, hanem az egyes gazdasági szereplők szintjén is megtörténik. Angol nyelvủ cikk vizsgálja a szervezeti sikert vagy bukást determináló, sokrétü tényezőként az okozati homályosság fontosságát. Végül a globalizált világrend átalakuló keretei közt óhatatlanul az egyes regionális tényezők is felmerülnek e fejezetben, így Kína és az Egyesült Királyság átalakuló szerepe, valamint a nemzetek közötti versenyképesség témája is. Csaba László Halmai Péter pályatársaként az illiberális kapitalizmus fenntarthatóságát elemzi. A piacgazdaságot és a tekintélyelvủ irányítást együttesen valló hibrid modellek, így Kína és a közép-európai országok példáján keresztül jut el azon végkövetkeztetéséhez, amely szerint a kínai út nehezen ültethető át és tartható fenn, míg a közép-európai változat kevésbé tekinthető modellszerünek, legfeljebb az európai fősodortól való hangsúlyeltolódásnak.

Az integráció iránti elkötelezettség a professzori életút központi eleme. Ugyanakkor a kritikai szemléletből fakadóan ez túlmutat az európai integráció vizsgálatán. Így annak fókuszában az európai növekedési potenciál eróziója, az európai növekedési és felzárkózási modell, az új tagországok növekedési modelljének sajátosságai állnak - kiemelt hangsúlyt helyezve e fejlődési modell utóbbi évtizedekben tapasztalható kifulladásának jeleire. Ennek okán rendkívül találó az emlékkötet harmadik fejezetének címe. Utóbbi - az Európa válaszúton - tematikus egységként vizsgálja, hogy a 2010-es évek végén, szűk hét évtized alatt meddig jutott el a kontinens annak megvalósításában, amit Schuman röviden anynyiban foglalt össze, hogy „lelket kell adni Európának”. A „,permanens válságok koraként" megjelölt jelen kori időszak megtépázta az Európai Uniót is. E fejezet szerzői ennek megfelelően kitérnek az európai növekedési és kapitalizmusmodellek elemzésére, az integráció jelenlegi helyzetére - így kiemelten a felmerülö kihívásokra és válaszlehetőségekre, a jelenlegi helyzet újrakitalált vagy revitalizált Európaként történő politológiai magyarázatával. Több elemzés is foglalkozik az uniós költségvetést érintő 2020 utáni változásokkal, a tágabb értelemben vett visegrádi térség, Magyarország felzárkózási lehetőségével, valamint az euró bevezetésének esélyével, a balti államok gazdaságát érintő növekedés jellegzetességeivel. A fejezet írásai tárgyalják a válaszúton lévő Európa absztraktabb, valamint ágazati kötődésű fejlődési elemeit: a technikai hatékonyság szerepét az EU mezőgazdaságában, a nemzetközi együttmüködés jelentőségét a tudásalapú agrárgazdaságban, az európai hadsereg kialakításának esélyeit, a korlátozott állam 
szerepét a válságkezelésben, az Európa-ökonómia szükségességét, az optimális valutaövezetek elméletét, végül a gazdaság és jog egymásra hatását az európai fogyasztóvédelmi versenyjogban. Bod Péter Ákos ugyancsak az ünnepelt pályatársaként járja körül az európai növekedési modell eróziójának kérdését. Ennek elemzésével arra a következtetésre jut, hogy inkább modellekről beszélhetünk, de adott tényezők vizsgálata mellett is nehéz régión belüli kisebb (lásd kelet-közép-európai növekedési) modellről értekezni. A válság utáni Európában a gazdasági kormányzás miatti további szuverenitástranszfer adott esetben dinamizmust adhat az európai növekedésnek, de ennek gyakorlati keretei még kialakításra várnak, valamint az sem egyértelmü, hogy Magyarország csatlakozik-e az integráltabb szisztémához.

A kötet olyan fejezettel, egyúttal témakörrel zárul, amely mindig is az ünnepelt által folytatott kutatások részét képezte, így ez a szerkezeti egység Magyarország szerepét vizsgálja a globalizált térben. Az eddig említett minden egyes tematikus egység magyar kötődéssel is bírt, kezdve a hazai átalakulás kritikai elemzésével, a globális és európai változási folyamatok, szakpolitikai keretek magyar szempontú feldolgozásával is. E fejezet írásai a legtágabb értelemben reflektálnak a 2010-es évek végének magyarországi kihívásaira mind gazdasági-politikai, mind társadalmi értelemben: kitérnek ennek megfelelően a különös magyar földöröklési rendszerekre, a hazai felsőoktatásra, az új Ptk. szerződési szabályozására, a magyar gazdasági kamarák helyére az európai kamarai tipológiában, végül a számvitel gazdaságtörténeti szerepére. Vékás Lajos angol nyelvü tanulmányában mutatja be az új Ptk. szerkezeti felépítését, a kontraktuális és deliktuális felelősség elhatárolásának témáját, a szerződésszegéssel okozott kárért való felelősség (kimentés) kérdését az új kódexben, végül az előreláthatóság követelményének fontosságát.

Nagy ívü kötetet érdemelt e gazdag tudományos pálya, amelynek koránt sincs még vége, hiszen ahogyan köszöntésekor az ünnepelt fogalmazott: „Az évek szállnak, mint a percek, de a lendület nem csökken. A fiatalság nem kronológiai kategória."

(Halm Tamás - Hurta Hilda - Koller Boglárka szerkesztök: Gazdasági, politikai és társadalmi kihívások a 21. században - Ünnepi kötet a 65. éves Halmai Péter tiszteletére. Budapest: Dialóg Campus Kiadó, 2018, 534 o.)

Szegedi László

egyetemi adjunktus, Nemzeti Közszolgálati Egyetem Nemzetközi és Európai Tanulmányok Kar 